Article

\title{
Computational Investigation of the Folded and Unfolded Band Structure and Structural and Optical Properties of $\mathrm{CsPb}\left(\mathrm{I}_{1-\mathrm{x}} \mathrm{Br}_{\mathrm{x}}\right)_{3}$ Perovskites
}

\author{
Hamid M. Ghaithan ${ }^{1,2, *}$, Zeyad A. Alahmed ${ }^{1, *(\mathbb{})}$, Andreas Lyras ${ }^{1}$, Saif M. H. Qaid ${ }^{1}\left({ }^{1}\right.$ and \\ Abdullah S. Aldwayyan 1,3,4,* \\ 1 Physics and Astronomy Department, College of Science, King Saud University, P.O. Box 2455, Riyadh 11451, \\ Saudi Arabia; alyras@ksu.edu.sa (A.L.); sqaid@ksu.edu.sa (S.M.H.Q.) \\ 2 Physics Department, College of Education and linguistic, Amran University, Amran 2915, Yemen \\ 3 King Abdullah Institute for Nanotechnology, King Saud University, P.O. Box 2454, \\ Riyadh 11451, Saudi Arabia \\ 4 K.A.CARE Energy Research and Innovation Center at Riyadh, P.O. Box 2022, Riyadh 11454, Saudi Arabia \\ * Correspondence: hghaithan@ksu.edu.sa (H.M.G.); zalahmed@ksu.edu.sa (Z.A.A.); \\ dwayyan@ksu.edu.sa (A.S.A.)
}

Received: 13 March 2020; Accepted: 20 April 2020; Published: 27 April 2020

\begin{abstract}
The structural, electronic, and optical properties of inorganic $\mathrm{CsPb}\left(\mathrm{I}_{1-\mathrm{x}} \mathrm{Br}_{\mathrm{x}}\right)_{3}$ compounds were investigated using the full-potential linear augmented-plane wave (FP-LAPW) scheme with a generalized gradient approximation (GGA). Perdew-Burke-Ernzerhof generalized gradient approximation (PBE-GGA) and modified Becke-Johnson GGA (mBJ-GGA) potentials were used to study the electronic and optical properties. The band gaps calculated using the mBJ-GGA method gave the best agreement with experimentally reported values. $\mathrm{CsPb}\left(\mathrm{I}_{1-x} \mathrm{Br}_{\mathrm{x}}\right)_{3}$ compounds were wide and direct band gap semiconductors, with a band gap located at the M point. The spectral weight (SW) approach was used to unfold the band structure. By substituting iodide with bromide, an increase in the band gap energy $\left(E_{g}\right)$ values of 0.30 and $0.55 \mathrm{eV}$, using PBE-GGA and mBJ-GGA potentials, respectively, was observed, whereas the optical property parameters, which were also investigated, demonstrated the reverse effect. The high absorption spectra in the ultraviolet-visible energy range demonstrated that $\mathrm{CsPb}\left(\mathrm{I}_{1-\mathrm{x}} \mathrm{Br}_{\mathrm{x}}\right)_{3}$ perovskite could be used in optical and optoelectronic devices by partly replacing iodide with bromide.
\end{abstract}

Keywords: $\mathrm{CsPb}\left(\mathrm{I}_{1-\mathrm{x}} \mathrm{Br}_{\mathrm{x}}\right)_{3}$ perovskite; PBE-GGA and mBJ-GGA; fold2Bloch; electronic and optical properties

\section{Introduction}

Halide perovskite $\mathrm{ABX}_{3}$ has attracted increasing interest as a potential solar cell material because of its simple fabrication techniques and outstanding optoelectronic properties. $\mathrm{ABX}_{3}$ perovskite materials have a high absorption coefficient, appropriate band gap $\left(\mathrm{E}_{\mathrm{g}}\right)$, and balanced electron and hole mobility [1-6]. In recent years, numerous researchers have focused on methylammonium lead trihalide perovskite $\left(\mathrm{CH}_{3} \mathrm{NH}_{3} \mathrm{PbX}_{3}\right)$, metal halide perovskite $\left(\mathrm{ABX} \mathrm{X}_{3}, \mathrm{~A}=\mathrm{Cs}, \mathrm{Rb} ; \mathrm{B}=\mathrm{Pb}, \mathrm{Sn} ; \mathrm{X}=\mathrm{Cl}, \mathrm{Br}\right.$, I), and $\mathrm{CsPbI}_{3}$, which have shown great potential $[7,8]$.

Most of the researchers have studied the structural, electronic, and optical properties of $\mathrm{CsPbX}_{3}(\mathrm{X}=$ $\mathrm{Cl}, \mathrm{Br}, \mathrm{I}$ ) using the density functional theory (DFT) and the WIEN2k package [8-11]. The $\mathrm{E}_{\mathrm{g}}$ tenability for $\mathrm{CsPbX}_{3}$ was studied experimentally [12], and the lattice modulation of $\mathrm{Cs}_{1-\mathrm{x}} \mathrm{R}_{\mathrm{x}} \mathrm{PbBr}_{3}(\mathrm{R}=\mathrm{Li}, \mathrm{Na}, \mathrm{K}, \mathrm{Rb}$, $x=0-1)$ was also investigated [13]. By doping the perovskite, the efficiency can be increased, as this can affect numerous electronic and optical properties [7]. The structural and electronic properties of all of the 
inorganic mixed-halide perovskites, $\mathrm{CsPb}\left(\mathrm{Br}_{1-\mathrm{x}} \mathrm{I}_{\mathrm{x}}\right)_{3}$ and $\mathrm{CsPb}\left(\mathrm{Cl}_{1-\mathrm{x}} \mathrm{Br}_{\mathrm{x}}\right)_{3}$, were investigated according to their halide composition using the Vienna ab initio simulation package (VASP) [14]. The accuracy of DFT calculations, i.e., how close they are to experimentally measured values, has been a concern for DFT calculations on perovskite since their recent introduction into solar cell and LED applications [15-21]. The accuracy of DFT calculations proved to be highly dependent on the exchange potential used in the calculations, such as local density approximation (LDA) [22], Perdew-Burke-Ernzerhof generalized gradient approximation (PBE-GGA) [23], modified Becke-Johnson GGA (mBJ-GGA) [24,25], Green function for the wave equation approximation (GW) [26,27], and hybrid functionals (HF) $[27,28]$. The HF and GW potentials have shown higher accuracy of the calculated band gap [26-28], but these functionals were more computationally expensive than LDA or PBE-GGA. The calculated band gap using LDA or PBE-GGA potentials was strongly underestimated because these functions contain a self-interaction error $[29,30]$. For example, calculation of the $E_{g}$ has varied greatly among many recent DFT reports, occasionally with considerable deviations from experimental values (band gap reported between 1.359-1.75 eV [8,9,31,32] compared to experimental values of $\sim 1.791 \mathrm{eV}[33,34]$ for $\mathrm{CsPbI}_{3}$ and $1.7-4.53 \mathrm{eV}[1,8,10,35-38]$ compared to experimental values of $\sim 2.3 \mathrm{eV}[13,39-44]$ for $\left.\mathrm{CsPbBr}_{3}\right)$. However, very accurate measurements of the band gaps of semiconductors and insulators were obtained when an orbital-independent exchange-correlation potential, mBJ-GGA, was used. This depended solely on semilocal quantities and was competitive in accuracy with the expensive HF and GW methods [24,45]. The supercell calculations are usually performed to allow minor modification of the crystal structure by replacing one atom with another atom. The most successful approach, spectral weight (SW), which links the supercell band structure with the primitive basis representation, is based on a Bloch spectral density [46]. One of the main challenges of supercell electronic structure calculations is to recover the Bloch character of electronic eigenstates [46]. To our knowledge, there have been no studies so far for a spectral weight (SW) approach which can be used to unfold the band structure of inorganic perovskite compounds by fold2Bloch package [46]. The fold2Bloch package was used in the past to unfold the band structure for other compounds such as GaAsBi [47], group (III-V and II-VI) semiconductor solid solutions [46], and graphene [48].

In this study, a combination of $\mathrm{CsPbI}_{3}$ and $\mathrm{CsPbBr}_{3}$ was proposed to tune the electronic and optical properties, using the full-potential linear-augmented plane wave (FP-LAPW) method $[49,50]$ within the framework of the DFT [22], as implemented in the WIEN2K code [51]. Here, an investigation into $\mathrm{CsPb}\left(\mathrm{I}_{1-\mathrm{x}} \mathrm{Br}_{\mathrm{x}}\right)_{3}$ (where $\mathrm{x}=0.00,0.25,0.50,0.75,1.00$ ) was performed to calculate the electronic and optical properties using PBE-GGA [23] and mBJ-GGA [24] methods. The structural properties were calculated using PBE-GGA potential. Unfolding the band structure of $\mathrm{CsPb}\left(\mathrm{I}_{1-x} \mathrm{Br}_{\mathrm{x}}\right)_{3}$ compounds for a number of Br fractions was performed by calculating the Bloch SW, using the fold2Bloch package [46] implemented in WIEN2k, in order to observe how the electronic properties of these compounds develop [47]. The visualization for electronic and structural analysis (VESTA) program was used for atomic structure visualization [52].

\section{Computational Method}

The ground state properties of $\mathrm{CsPb}\left(\mathrm{I}_{1-\mathrm{x}} \mathrm{Br}_{\mathrm{x}}\right)_{3}$ were calculated by the FP-LAPW method [50] within the framework of the DFT [22,49], as implemented in the WIEN2K code [51]. The PBE-GGA and mBJ-GGA potentials were used to calculate the electronic properties of $\mathrm{CsPb}\left(\mathrm{I}_{1-\mathrm{x}} \mathrm{Br}_{\mathrm{x}}\right)_{3}$ perovskite $[23,24]$. To simulate $\mathrm{CsPb}\left(\mathrm{I}_{1-\mathrm{x}} \mathrm{Br}_{\mathrm{x}}\right)_{3}(\mathrm{x}=0.00,0.25,0.50,0.75,1.00)$, a $1 \times 1 \times 4$ supercell with 20 atoms was used. For $x=0.25$, three atoms of iodide were substituted with three atoms of bromide. For $x=0.50$, six atoms of iodide were substituted with six atoms of bromide. For $x=0.75$, nine atoms of iodide were substituted with nine atoms of bromide. For $\mathrm{x}=1.00$, twelve atoms of iodide were substituted with twelve atoms of bromide.

The muffin-tin radius $\mathrm{R}_{\mathrm{MT}}$ was chosen with no charge leakage from the core, and total energy convergence was ensured. The convergence of the basis set was controlled by the cutoff parameter, $\mathrm{R}_{\mathrm{MT}} \cdot \mathrm{K}_{\max }=9$, where $K_{\max }$ is the largest reciprocal lattice vector used in the plane wave expansion 
within the interstitial region. The magnitude of the largest vector in the charge density Fourier expansion was $G_{\max }=12 \cdot(a . u)^{-1}$. The Brillouin zones were sampled with a $12 \times 12 \times 12$ k-point mesh for the unit cell and a $15 \times 15 \times 3 \mathrm{k}$-point mesh for the supercell. The energy cutoff was chosen as $-6.0 \mathrm{Ry}$, which defines the separation of the valence and core states. The charge convergence was selected as $0.0001 \mathrm{e}$ during the self-consistency cycles. The unfolded band structure of $\mathrm{CsPb}\left(\mathrm{I}_{1-\mathrm{x}} \mathrm{Br}_{\mathrm{x}}\right)_{3}$ compounds was determined by calculating the Bloch SW, using fold2Bloch package [46] implemented in WIEN2k, which is available from GitHub [46]. See the Supplementary Materials for more details about fold2Bloch package.

\section{Results and Discussions}

\subsection{Structural Properties}

The crystal structures of cubic $\mathrm{CsPbX}_{3}$ with the atomic positions of $\mathrm{Cs}$ at $(0,0,0), \mathrm{Pb}$ at $(0.5,0.5$, $0.5)$, and $X$ at $(0.5,0.5,0)$ within the $P m \overline{3} \mathrm{~m}$ space group were evaluated through these calculations. $\mathrm{The} \mathrm{CsPb}\left(\mathrm{I}_{1-\mathrm{x}} \mathrm{Br}_{\mathrm{x}}\right)_{3}$ semiconductor compounds were modeled at the selected compositions with ordered structures of periodically repeating supercells $1 \times 1 \times 4$ with 20 atoms per unit cell for $x=0.00,0.25,0.50$, 0.75, and 1.00, as shown in Figure 1. See the Supplementary Materials, Tables S1-S5 for more details.

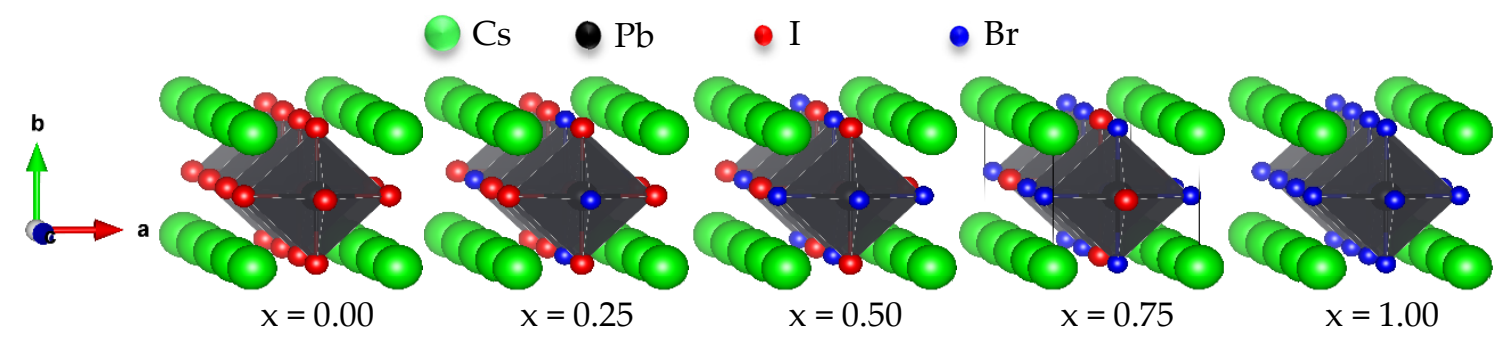

Figure 1. Atomic structures of $\mathrm{CsPb}\left(\mathrm{I}_{1-\mathrm{x}} \mathrm{Br}_{\mathrm{x}}\right)_{3}$, with $\mathrm{x}=0.00,0.25,0.50,0.75$, and 1.00 for the different mixed ratios of $x$.

The computed lattice parameters for cubic $\mathrm{CsPbBr}_{3}, \mathrm{CsPbI}_{3}$, and their compounds using PBE-GGA potential were in good agreement with previous experimental and theoretical values, as listed in Table 1 . Figure 2 shows that the unit-cell volume varies linearly as a function of the ratio $x$, which is in agreement with Vegard's law [14].

Table 1. Calculated lattice constants $(\AA)$, bulk moduli B (GPa), and the pressure derivatives B' using Perdew-Burke-Ernzerhof generalized gradient approximation (PBE-GGA) potential compared with previous results.

\begin{tabular}{|c|c|c|c|c|c|c|}
\hline \multirow{2}{*}{$\operatorname{CsPb}\left(I_{1-x} B_{x}\right)_{3}$} & \multicolumn{2}{|c|}{ Lattice Constants (̊̊) } & \multirow{2}{*}{$\begin{array}{c}\text { Unit-Cell Volume } \mathrm{V}\left(\AA \AA^{3}\right)^{3} \\
\text { This Study }\end{array}$} & \multicolumn{2}{|c|}{ B (GPa) } & \multirow{2}{*}{$\begin{array}{c}\text { B' }^{\prime} \\
\text { This Study }\end{array}$} \\
\hline & This Study & Previous Studies (Exp.) & & This Study & Previous Studies & \\
\hline $\mathrm{CsPbI}_{3}$ & 6.28 & $\begin{array}{c}6.40 \text { [9] (PBE-GGA) } \\
6.4004 \text { [53] (PBE-GGA) } \\
6.14 \text { [9] (LDA) } \\
6.25 \text { [9] (PBEsol-GGA) } \\
6.39 \text { [14] (PBE-GGA) } \\
(6.29)[54] \\
(6.18)[55]\end{array}$ & 990.69 & 14.5770 & $\begin{array}{c}14.3971 \text { [9] } \\
\text { (PBE-GGA) } \\
20.220 \text { [9] (LDA) } \\
16.910 \text { [9] } \\
\text { (PBEsol-GGA) }\end{array}$ & 4.502 \\
\hline $\mathrm{CsPb}\left(\mathrm{I}_{0.75} \mathrm{Br}_{0.25}\right)_{3}$ & 6.1775 & 6.395 [14] (PBE-GGA) & 942.97 & - & - & - \\
\hline $\mathrm{CsPb}\left(\mathrm{I}_{0.5} \mathrm{Br}_{0.5}\right)_{3}$ & 6.075 & 5.990 [14] (PBE-GGA) & 896.81 & - & - & - \\
\hline $\mathrm{CsPb}\left(\mathrm{I}_{0.25} \mathrm{Br}_{0.75}\right)_{3}$ & 5.9725 & 5.997 [14] (PBE-GGA) & 852.17 & - & - & - \\
\hline $\mathrm{CsPbBr}_{3}$ & 5.87 & $\begin{array}{c}6.0051 \text { [8] (PBE-GGA) } \\
6.00549 \text { [53] (PBE-GGA) } \\
6.009 \text { [31] (PBE-GGA) } \\
5.875 \text { [56] (PBEsol-GGA) } \\
6.046 \text { [31] (HSE) } \\
5.999 \text { [14] (PBE-GGA) } \\
5.84 \text { [57] (WC-GGA) } \\
\text { (5.874) [58] }\end{array}$ & 809.05 & 18.7612 & - & 4.2192 \\
\hline
\end{tabular}




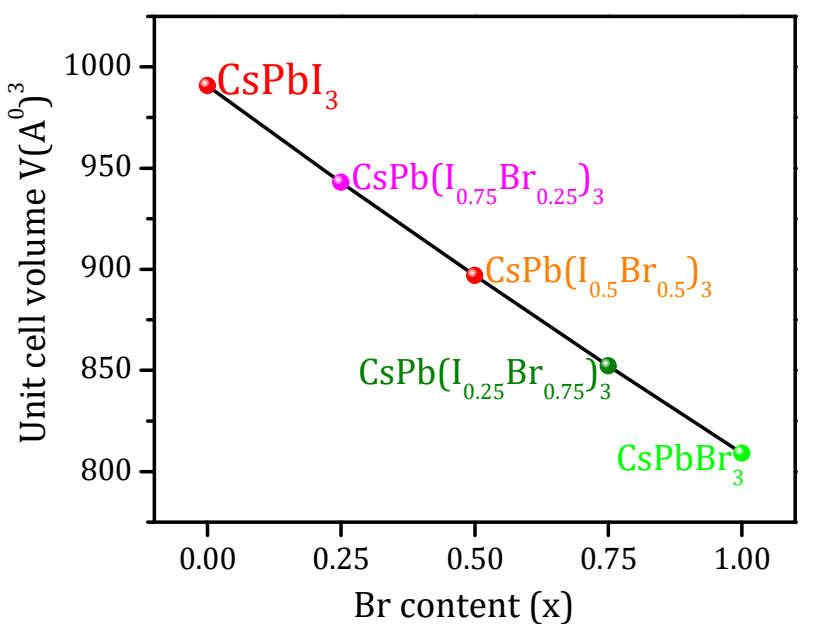

Figure 2. The unit-cell volumes vary linearly as a function of Br content (x).

\subsection{Electronic Properties}

The electronic properties of $\mathrm{CsPb}\left(\mathrm{I}_{1-\mathrm{x}} \mathrm{Br}_{\mathrm{x}}\right)_{3}$ were studied by calculating the energy band structure. The folded band structure calculations at $x=0.00,0.25,0.50,0.75$, and 1.00 were performed using both PBE-GGA and mBJ-GGA methods. The calculated folded band structures along the wave vectors $\mathrm{X}, \mathrm{M}$, and $\Gamma$ in the Brillouin zone, using mBJ-GGA potential, are shown in Figure 3a-e. In order to study the behavior of $\mathrm{E}_{\mathrm{g}}$ with the composition $\mathrm{x}$ of $\mathrm{Br}$, the variation of $\mathrm{E}_{\mathrm{g}}$ versus the concentration obtained using the PBE-GGA and mBJ-GGA methods was calculated. Here, $\mathrm{E}_{\mathrm{g}}$ increased with an increasing $\mathrm{Br}$ concentration, as shown in Figure 4. The folded band structures using PBE-GGA are available in the Supplementary Materials, Figure S1.

The substitution of bromide atoms at the iodide sites in the $\mathrm{CsPbI}_{3}$ compound provided a direct band gap character $(\mathrm{M} \rightarrow \mathrm{M})$. The overall behavior of the folded band structures calculated by these two approximations was similar, except for the value of $\mathrm{E}_{\mathrm{g}}$, which was higher for the mBJ-GGA method, as listed in Table 2. The calculated $\mathrm{E}_{\mathrm{g}}$ of $\mathrm{CsPb}\left(\mathrm{I}_{1-\mathrm{x}} \mathrm{Br}_{\mathrm{x}}\right)_{3}$, using the mBJ-GGA method, agreed with the experimental values, as listed in Table 2 and shown in Figure 4. Therefore, it could be concluded that the mBJ-GGA potential presents a good approach for calculating the electronic properties for a wide range of materials, such as wide-band-gap insulators, semiconductors, and three-dimensional transition-metal oxides, particularly their band gaps [24,45,59-61].

The folded band structure calculation for a 20 -atom supercell of $\mathrm{CsPb}\left(\mathrm{I}_{1-\mathrm{x}} \mathrm{Br}_{\mathrm{x}}\right)_{3}$ represents a zone folding that hinders the analysis of the band structure of supercells, and the direct character of the folded band gap is obscured [46]. In order to recover the $\mathrm{CsPb}\left(\mathrm{I}_{1-x} \mathrm{Br}_{x}\right)_{3}$ band structure in its conventional Bloch representation, the SW approach was applied to unfold the electronic structure obtained from the framework of density functional theory, using the all-electron Wien $2 \mathrm{k}$ package. The calculation of the SW is based on remapping the supercell reciprocal space with a mesh that is compatible with the translational symmetry of a primitive cell [46]. The unfolded band structure calculation for a 20-atom supercell $1 \times 1 \times 4$ was calculated as shown in Figure $3 \mathrm{f}-\mathrm{j}$ and can be directly compared to that in Figure 3a-e. The unfolded band structure for the pure supercell $\mathrm{CsPbI}_{3}$ is shown in Figure $3 \mathrm{f}$. Due to the increases in the doping level of $\mathrm{Br}$, the unfolded band structure becomes more obvious (Figure 3g-j). In another words, the colors in the conduction band minimum (CBM) and valence band maximum (VBM) change, which indicate the Bloch spectral weights as shown in the right axis of Figure 3. The SW is determined by both degeneracy and magnitude of the corresponding Bloch character [46,62-64]. 




Figure 3. (a-e) Calculated folded band structures of $\mathrm{CsPbI}_{3}, \mathrm{CsPb}\left(\mathrm{I}_{0.75} \mathrm{Br}_{0.25}\right)_{3}, \mathrm{CsPb}\left(\mathrm{I}_{0.5} \mathrm{Br}_{0.5}\right)_{3}$, $\mathrm{CsPb}\left(\mathrm{I}_{0.25} \mathrm{Br}_{0.75}\right)_{3}$, and $\mathrm{CsPbBr}{ }_{3}$ using the (most accurate) modified Becke-Johnson generalized gradient approximation (mBJ-GGA) method. ( $\mathbf{f}-\mathbf{j})$ Band structures obtained by the first-principle simulations equipped with fold2Bloch function at $\mathrm{Br}$ fractions of $\%, 25 \%, 50 \%, 75 \%$, and $100 \%$ respectively. The color scale at the bottom right indicates the Bloch spectral weights.

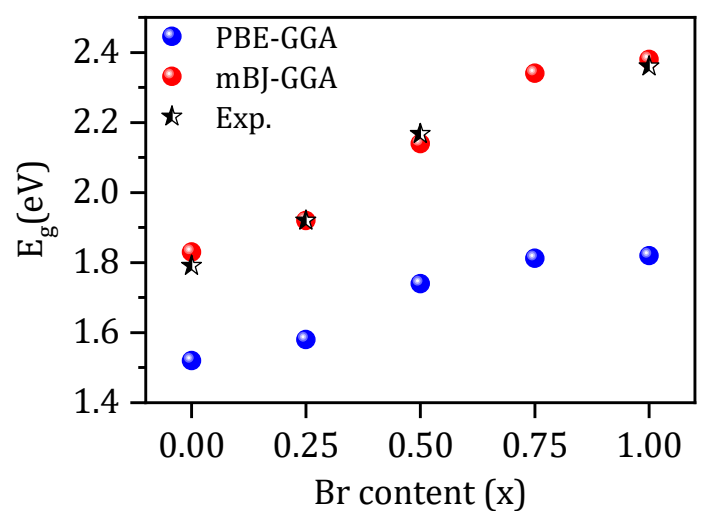

Figure 4. Compositional dependence of the $E_{\mathrm{g}}$ calculated using the PBE-GGA and mBJ-GGA methods, compared with experimental values $[12,13,33]$. 
Table 2. Calculated $\mathrm{E}_{\mathrm{g}}$ (in $\left.\mathrm{eV}\right)$ of $\mathrm{CsPb}\left(\mathrm{I}_{1-\mathrm{x}} \mathrm{Br}_{\mathrm{x}}\right)_{3}$ compared to the experimental and density functional theory (DFT) calculated values.

\begin{tabular}{|c|c|c|c|c|}
\hline \multirow{3}{*}{$\begin{array}{c}\mathrm{CsPb}\left(\mathrm{I}_{1-\mathrm{x}} \mathrm{Br}_{\mathrm{x}}\right)_{3} \\
\mathrm{x}=\end{array}$} & \multicolumn{4}{|c|}{$E_{g}(e V)$} \\
\hline & \multicolumn{2}{|c|}{ This Study } & \multicolumn{2}{|c|}{ Other Calculations } \\
\hline & PBE-GGA & mBJ-GGA & Theoretical & Experimental \\
\hline 0.00 & 1.52 & 1.83 & $\begin{array}{c}1.485 \text { [32] (PBE-GGA) } \\
1.938 \text { [32] (HSE06) } \\
1.359 \text { [31] (PBE-GGA) } \\
1.56 \text { [9] (PBE-GGA) } \\
1.879 \text { [9] (mBJ-GGA) } \\
1.478 \text { [8] (PBE-GGA) } \\
1.75 \text { [8] (nTmBJ) } \\
1.90 \text { [53] (PBE-GGA) }\end{array}$ & $\begin{array}{c}1.791[33] \\
1.73[34]\end{array}$ \\
\hline 0.25 & 1.58 & 1.92 & - & $1.92[12]$ \\
\hline 0.50 & 1.74 & 2.14 & - & $2.167[33]$ \\
\hline 0.75 & 1.81 & 2.34 & - & - \\
\hline 1.00 & 1.82 & 2.38 & $\begin{array}{c}1.60 \text { [57] (WC-GGA) } \\
2.41 \text { [65] (HSE) } \\
1.482 \text { [14] (PBE-GGA) } \\
1.764 \text { [31] (PBE-GGA) } \\
2.50 \text { [53] (PBE-GGA) }\end{array}$ & $\begin{array}{c}2.30[66] \\
2.36[67] \\
2.32[13] \\
2.282[68]\end{array}$ \\
\hline
\end{tabular}

\subsection{Density of States}

The total density of states (TDOS) and partial density of states (PDOS) based on the variable control approach were determined to further reveal the factors controlling the $\mathrm{E}_{\mathrm{g}}$ trends. In order to study the effect of replacing iodide by bromide on $\mathrm{E}_{\mathrm{g}}$ trend, the TDOS were calculated using PBE-GGA and mBJ-GGA methods shown in Figure $5 a, b$. The overall feature of the TDOS remains the same in $\mathrm{CsPb}\left(\mathrm{I}_{1-\mathrm{x}} \mathrm{Br}_{\mathrm{x}}\right)_{3}$ compounds. However, by increasing the concentration of $\mathrm{x}$ from 0.00 to 1.00 , the edges of TDOS show upshifts. Figure 6 shows the calculated PDOS with various doping concentrations, using mBJ-GGA potential. For all concentrations, the Cs atom makes a negligible contribution to the valence band maximum (VBM) or conduction band minimum (CBM).



(a)

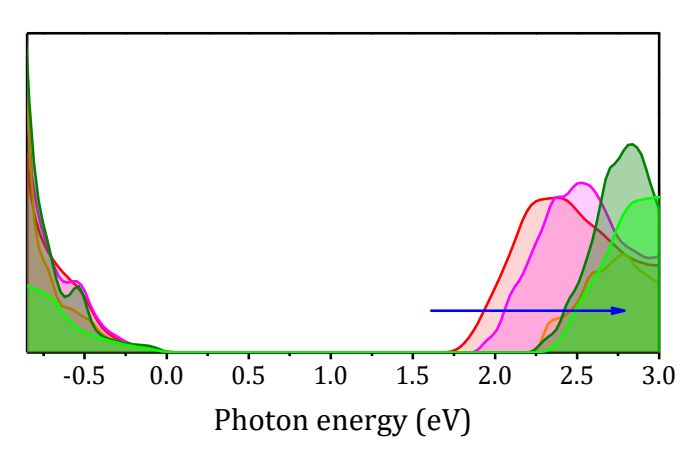

(b)

Figure 5. Calculated total density of states (TDOS) of $\mathrm{CsPb}\left(\mathrm{I}_{1-\mathrm{x}} \mathrm{Br}_{\mathrm{x}}\right)_{3}$ with various doping concentrations by (a) PBE-GGA and (b) mBJ-GGA potentials where the valence band maximum (VBM) is shifted to $0 \mathrm{eV}$. 


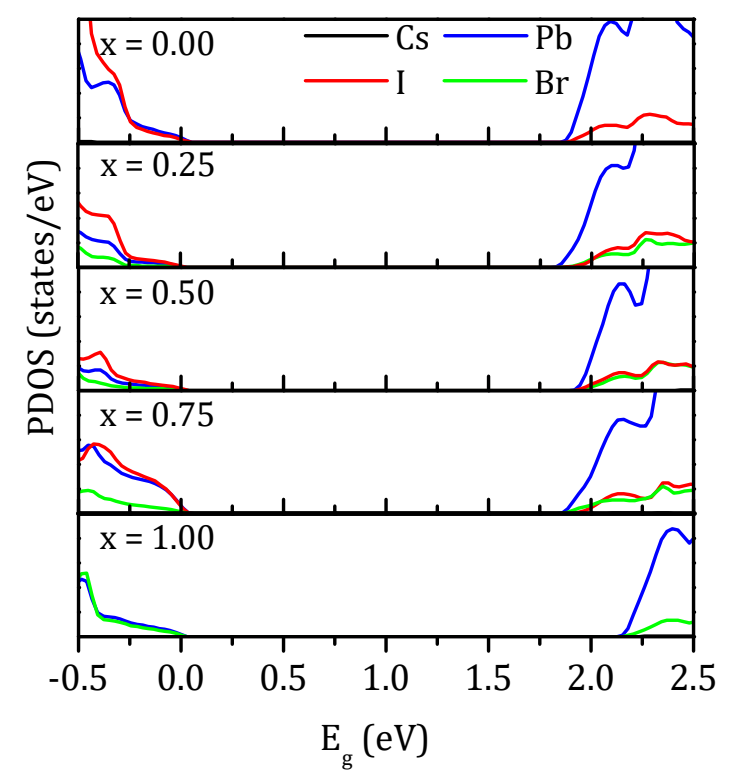

Figure 6. Calculated partial density of states (PDOS) of $\mathrm{CsPb}\left(\mathrm{I}_{1-\mathrm{x}} \mathrm{Br}_{\mathrm{x}}\right)_{3}$ using the mBJ-GGA potential.

\subsection{Optical Properties}

The optical properties of a material, according to Maxwell's equations, are based on characteristic constants of matter, such as the dielectric constant, magnetic permeability, and electrical conductivity, which are functions of the frequency $(\omega)$ of the incident photon [9].

The incident photon interacts with the constituent atoms, and subsequently, the dielectric function $\varepsilon(\omega)$ describes the optical response of a material. In Figure 7, the imaginary parts $\varepsilon_{2}(\omega)$ of the calculated dielectric functions are shown using the results of the mBJ-GGA method. The optical parameters, including refraction, reflection, and absorption, can be derived from the real and imaginary parts of the dielectric function $[9,69]$. The complete response of a material to the disturbances caused by electromagnetic radiation is described by the complex dielectric function [57]. The imaginary part of the function $\varepsilon_{2}(\omega)$ is related to the band structure and describes its absorptive behavior [57]. The critical (start) points in the spectra of $\varepsilon_{2}(\omega)$ were at 1.79, 1.945, 2.11, 2.26, and $2.33 \mathrm{eV}$ for $\mathrm{CsPbI}_{3}, \mathrm{CsPb}\left(\mathrm{I}_{0.75} \mathrm{Br}_{0.25}\right)_{3}$, $\mathrm{CsPb}\left(\mathrm{I}_{0.5} \mathrm{Br}_{0.5}\right)_{3}, \mathrm{CsPb}\left(\mathrm{I}_{0.25} \mathrm{Br}_{0.75}\right)_{3}$, and $\mathrm{CsPbBr}$, respectively, which are closely related to the band gaps of $1.78,1.89,2.21,2.23$, and $2.34 \mathrm{eV}$, respectively.

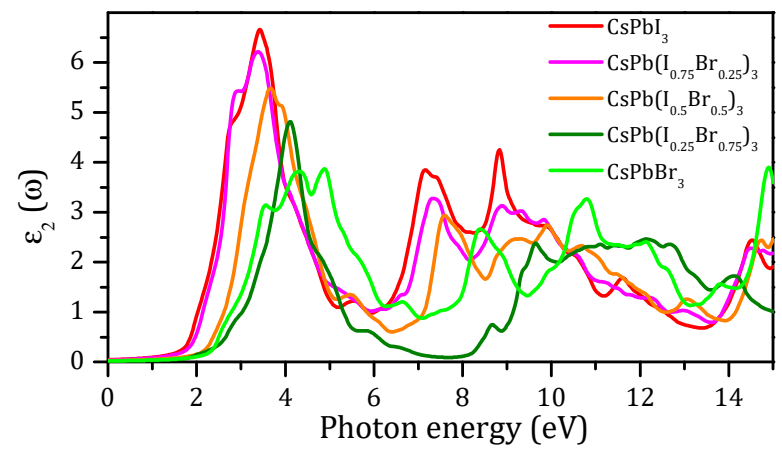

Figure 7. Calculated $\varepsilon_{2}(\omega)$ for $\mathrm{CsPbI}_{3}, \mathrm{CsPb}\left(\mathrm{I}_{0.75} \mathrm{Br}_{0.25}\right)_{3}, \mathrm{CsPb}\left(\mathrm{I}_{0.5} \mathrm{Br}_{0.5}\right)_{3}, \mathrm{CsPb}\left(\mathrm{I}_{0.25} \mathrm{Br}_{0.75}\right)_{3}$, and $\mathrm{CsPbBr}_{3}$ as a function of photon energy.

The optical conductivity spectra, $\sigma(\omega)$, shown in Figure 8a, demonstrate that optical conductance started at approximately $1.728,1.864,2.13,2.48$, and $2.54 \mathrm{eV}$ for $\mathrm{x}=0.00,0.25,0.50,0.75$, and 1.00, respectively; the $\sigma(\omega)$ values reached their maxima and then decreased with small variations $[57,70]$. Similar features were also observed for the absorption coefficients $\alpha(\omega)$ (Figure $8 b$ ) and extinction 
coefficients $\mathrm{k}(\omega)$ (Figure $8 \mathrm{c}$ ). The wide absorption range suggests that these compounds could be used for various optical and optoelectronic devices in this range of the EM spectrum. Moreover, the absorption range could be tuned by varying the composition fraction with values for $\mathrm{x}$ between 0.00 and 1.00 .

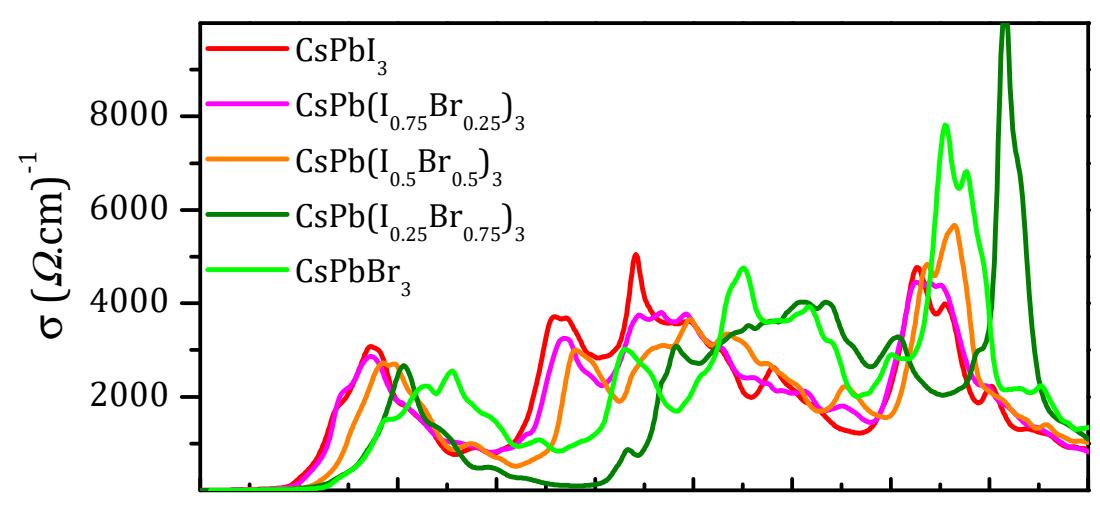

(a)

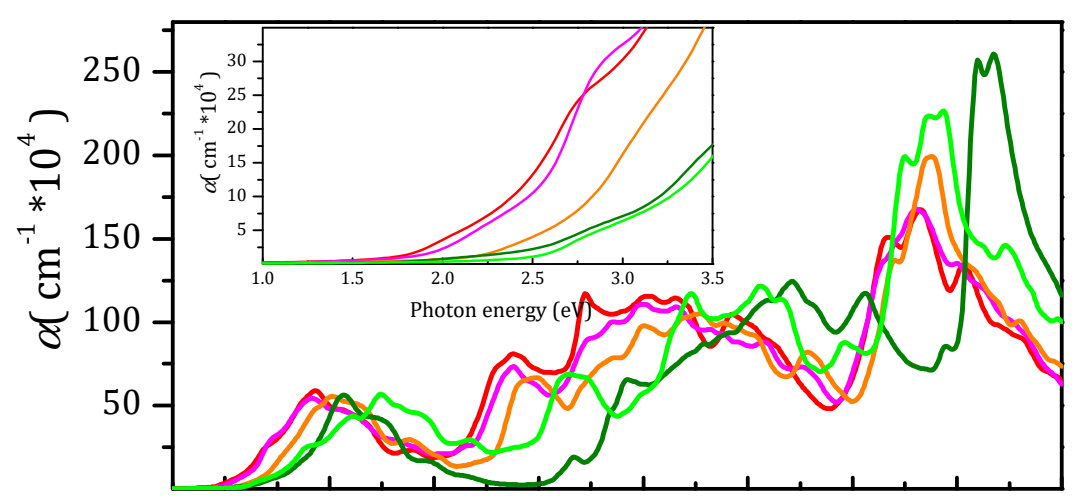

(b)

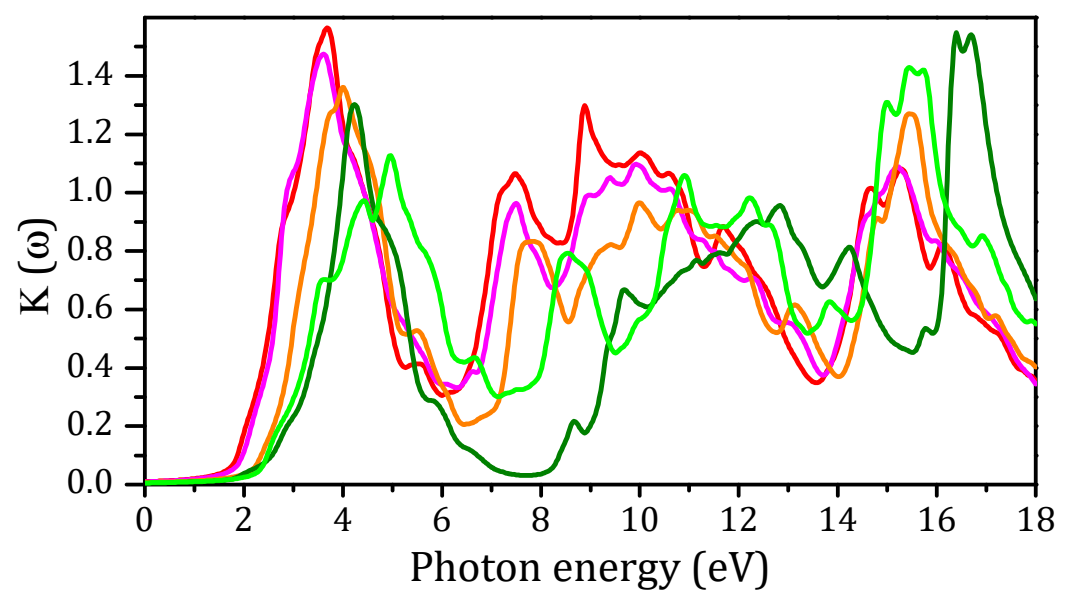

(c)

Figure 8. Calculated optical conductivity $\sigma(\omega)(\mathbf{a})$, absorption coefficient $\alpha(\omega)$ (inset: absorption spectra in the range from 1.0 to $3.5 \mathrm{eV})(\mathbf{b})$, and extinction coefficient $\mathrm{k}(\omega)(\mathbf{c})$ as functions of photon energy for $\mathrm{CsPbI}_{3}, \mathrm{CsPb}\left(\mathrm{I}_{0.75} \mathrm{Br}_{0.25}\right)_{3}, \mathrm{CsPb}\left(\mathrm{I}_{0.5} \mathrm{Br}_{0.5}\right)_{3}, \mathrm{CsPb}\left(\mathrm{I}_{0.25} \mathrm{Br}_{0.75}\right)_{3}$, and $\mathrm{CsPbBr}_{3}$.

Figure 9a shows the variation of the real dielectric function $\varepsilon_{1}(\omega)$ with energy. In this spectra, the zero frequency limit $\varepsilon_{1}(0)$ was the most important quantity that represented the electronic part of the static dielectric constant [57]. Here, $\varepsilon_{1}(\omega)$ increased from the zero frequency limit to the maximum 
value and then decreased to below zero. The calculated $\varepsilon_{1}(0)$ is shown in Table 3. As seen in Table 3, $\varepsilon_{1}(0)$ decreased as $\mathrm{x}$ increased from 0.00 to 1.00, demonstrating an inverse relation between $\mathrm{Br}$ content $(\mathrm{x})$ and $\varepsilon_{1}(0)$, see Figure 10.

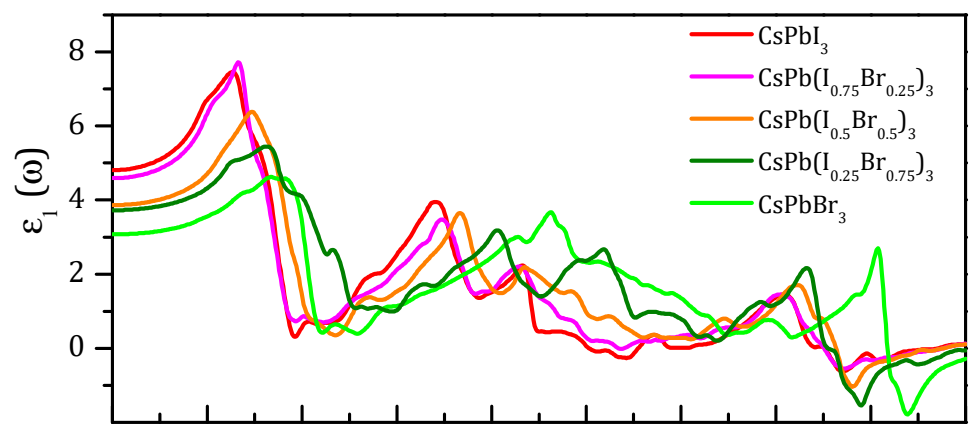

(a)

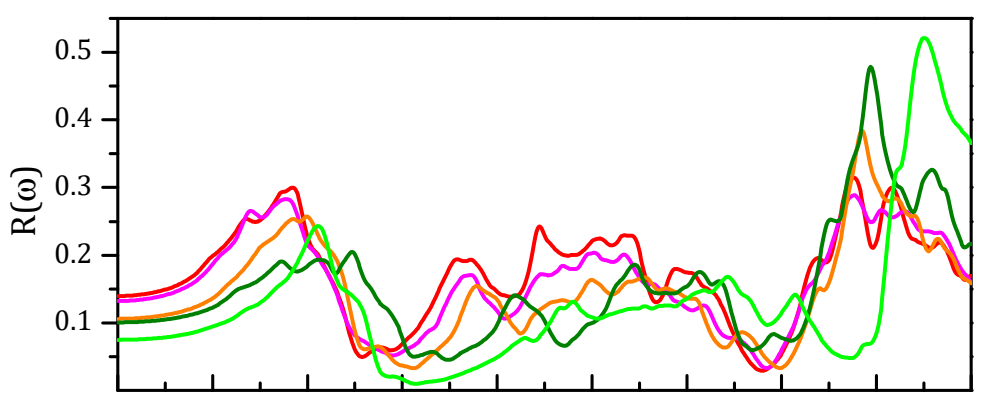

(b)

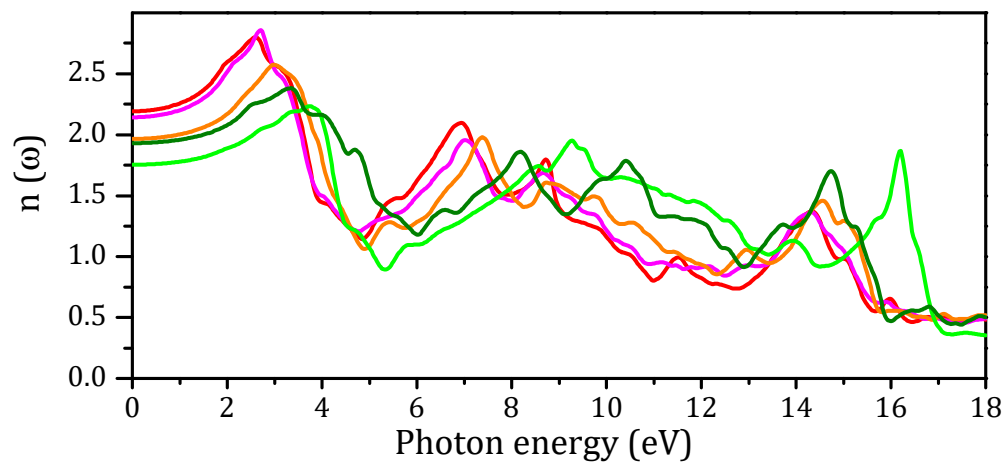

(c)

Figure 9. Calculated $\varepsilon_{1}(\omega)(\mathbf{a}), \mathrm{R}(\omega)(\mathbf{b})$, and $\mathrm{n}(\omega)(\mathbf{c})$ as a function of photon energy.

Table 3. Calculated zero frequency limits of $\varepsilon_{1}(0), \mathrm{R}(0)$, and $\mathrm{n}(0)$.

\begin{tabular}{cccccc}
\hline Parameters & $\mathbf{x}=\mathbf{0 . 0 0}$ & $\mathbf{x}=\mathbf{0 . 2 5}$ & $\mathbf{x}=\mathbf{0 . 5 0}$ & $\mathbf{x}=\mathbf{0 . 7 5}$ & $\mathbf{x = 1 . 0 0}$ \\
\hline \multirow{2}{*}{$\varepsilon_{1}(0)$} & 4.82 & 4.60 & 3.87 & 3.73 & 3.08 \\
& $6.003[57]$ & - & - & - & $4.631[57]$ \\
\hline \multirow{2}{*}{$\mathrm{R}(0)$} & 0.14 & 0.13 & 0.11 & 0.10 & 0.07 \\
& $0.177[57]$ & - & - & - & $0.134[57]$ \\
\hline \multirow{2}{*}{$\mathrm{n}(0)$} & 2.19 & 2.14 & 1.96 & 1.93 & 1.75 \\
& $2.45[57]$ & - & - & - & $1.928[57]$ \\
\hline
\end{tabular}




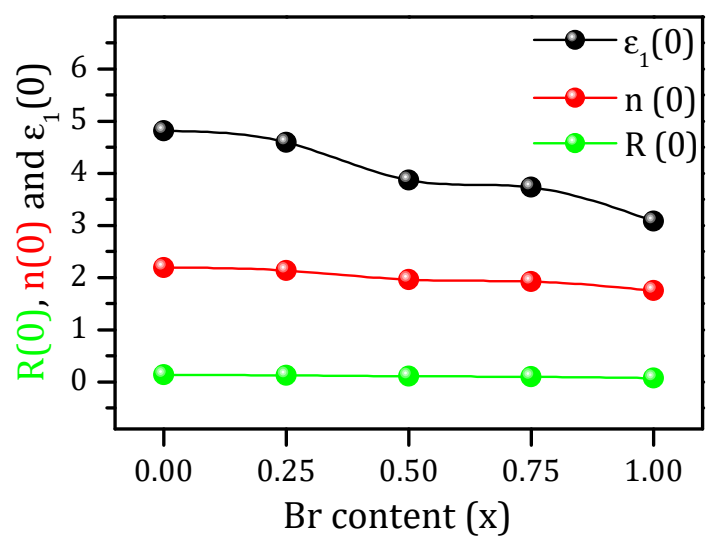

Figure 10. Zero frequency limit of $\varepsilon_{1}(0), \mathrm{n}(0)$, and $\mathrm{R}(0)$ vs. Br content $(\mathrm{x})$.

The frequency-dependent reflectivity $R(\omega)$ for these compounds is shown in Figure $9 b$, while the zero frequency reflectivities are listed in Table 3 . In addition, $R(0)$ increased in a similar way to $\varepsilon_{1}(0)$ as the change of anion concentration $x$ increases from 0.00 to 1.00. As Figure $9 a, b$ shows, the maximum $R(\omega)$ occurred when $\varepsilon_{1}(\omega)$ reached a negative value; thus, the material exhibited a dielectric behavior $\left(\varepsilon_{1}(\omega)\right.$ $>0)$; Below zero, the material demonstrated metallic properties $\left(\varepsilon_{1}(\omega)<0\right)[57,71]$. The maximum range of $R(\omega)$ increased with the metallicity when $\varepsilon_{1}(\omega)$ was negative [9]. The reflectivity $R(w)$ was initially $14.1 \%$ and reached a maximum value of $31.3 \%$ for $\mathrm{CsPbI}_{3}$; for $\mathrm{CsPb}\left(\mathrm{I}_{0.75} \mathrm{Br}_{0.25}\right)_{3}, \mathrm{R}(\omega)$ was initially $13.1 \%$ and increased to $28.7 \%$; for $\mathrm{CsPb}\left(\mathrm{I}_{0.5} \mathrm{Br}_{0.5}\right)_{3}, \mathrm{R}(\omega)$ was initially $10.7 \%$ and reached a maximum value of $38.5 \%$; for $\mathrm{CsPb}\left(\mathrm{I}_{0.25} \mathrm{Br}_{0.75}\right)_{3}, \mathrm{R}(\omega)$ was initially $7.6 \%$ and reached a maximum value of $52.2 \%$; and for $\mathrm{CsPbBr}_{3}, \mathrm{R}(\omega)$ was initially $10 \%$ and reached a maximum value of $47.9 \%$. The maximum reflectivity peak decreased as $x$ approached 1.00 [66]. The calculated $R(0)$ is shown in Table 3 and Figure 10 which show that $R(0)$ decreased as $x$ increased from 0.00 to 1.00 .

Figure $9 \mathrm{c}$ shows the refractive indices $\mathrm{n}(\omega)$ as a function of the incident photon energy. The spectrum of $n(\omega)$ closely followed $\varepsilon_{1}(\omega)[57,70]$. From Figure $9 c, n(\omega)$ of the material increased with an increasing $\mathrm{Br}$ concentration in $\mathrm{CsPbI}_{3}$ from the zero frequency limits and reached the maximum values of 2.8, 2.85, 2.57, 2.234, and 2.38 for $\mathrm{CsPbI}_{3}, \mathrm{CsPb}\left(\mathrm{I}_{0.75} \mathrm{Br}_{0.25}\right)_{3}, \mathrm{CsPb}\left(\mathrm{I}_{0.5} \mathrm{Br}_{0.5}\right)_{3}, \mathrm{CsPb}\left(\mathrm{I}_{0.25} \mathrm{Br}_{0.75}\right)_{3}$, and $\mathrm{CsPbBr}_{3}$, respectively. After $\mathrm{n}(\omega)$ reached the maximum value, it decreased to below unity in certain energy ranges; thus, the group velocity $\left(\mathrm{V}_{\mathrm{g}}=\mathrm{c} / \mathrm{n}\right)$ of the incident radiation was greater than $\mathrm{c}[57,70]$. The group velocity shifted to a negative domain, and the nature of the medium changed from linear to nonlinear or the material became superluminal for high energy photons $[57,70]$. The calculated $n(0)$ is shown in Table 3, and Figure 10 shows that $n(0)$ decreased as $x$ increased from $=0.00$ to 1.00 .

\section{Conclusions}

The structural, electronic, and optical properties of $\mathrm{CsPb}\left(\mathrm{I}_{1-\mathrm{x}} \mathrm{Br}_{\mathrm{x}}\right)_{3}(\mathrm{x}=0.00,0.25,0.50,0.75$ and 1.00) were investigated using the FP-LAPW scheme within the framework of the GGA. The two exchange potentials, PBE-GGA and mBJ-GGA, were used to study the electronic and optical properties. In this study, a variation in the $\mathrm{E}_{\mathrm{g}}$ values $(1.83,1.92,2.14,2.34$, and $2.38 \mathrm{eV})$ was observed with the increasing concentration of $\mathrm{Br}$ atoms in the $\mathrm{CsPb}\left(\mathrm{I}_{1-\mathrm{x}} \mathrm{Br}_{\mathrm{x}}\right)_{3}$ compounds using the mBJ-GGA potential, while another variation in $\mathrm{E}_{\mathrm{g}}$ values $(1.52,1.58,1.74,1.81$, and $1.82 \mathrm{eV})$ was observed using the PBE-GGA potential. $\mathrm{CsPb}\left(\mathrm{I}_{1-\mathrm{x}} \mathrm{Br}_{\mathrm{x}}\right)_{3}$ compounds were found to be wide and direct band gap semiconductors with $\mathrm{E}_{\mathrm{g}}$ located at the M-symmetry wave vector. The effects of the substitution of I by $\mathrm{Br}$ on the electronic structure were studied from first principles. By controlling the portion of $\mathrm{Br}$, the unfolded band structure was obtained by both degeneracy and magnitude of the corresponding Bloch character, leading to color changes in CBM and VBM. The optical properties, such as the optical conductivities, absorption coefficients, real and imaginary parts of the dielectric functions, refractive indices, extinction coefficients, and reflectivities, were also calculated. The direct $E_{g}$ and high absorption spectra of these compounds in the ultraviolet-visible energy range demonstrated that the perovskite could be used 
in optical and optoelectronic devices in this range of the spectrum by varying the level of $x$ in the composition of the compound.

Supplementary Materials: The following are available online at http://www.mdpi.com/2073-4352/10/5/342/s1, Tables S1-S5: Structural properties of $\left.\mathrm{CsPb}_{1} \mathrm{I}_{1-\mathrm{x}} \mathrm{Br}_{\mathrm{x}}\right)_{3}$ Perovskite, Figure S1: Calculated the band structures of $\mathrm{CsPbI}_{3}, \mathrm{CsPb}\left(\mathrm{I}_{0.75} \mathrm{Br}_{0.25}\right)_{3}, \mathrm{CsPb}\left(\mathrm{I}_{0.5} \mathrm{Br}_{0.5}\right)_{3}, \mathrm{CsPb}\left(\mathrm{I}_{0.25} \mathrm{Br}_{0.75}\right)_{3}$, and $\mathrm{CsPbBr}_{3}$ using the PBE-GGA method, fold2Bloch package.

Author Contributions: Conceptualization, H.M.G., Z.A.A., and A.S.A.; methodology, H.M.G. and Z.A.A.; software, H.M.G. and Z.A.A.; validation, Z.A.A., A.S.A. and S.M.H.Q.; formal analysis, H.M.G. and Z.A.A.; investigation, H.M.G., Z.A.A. and A.S.A.; data curation, H.M.G. and Z.A.A.; writing-original draft preparation, H.M.G.; writing-review and editing, Z.A.A., A.S.A., S.M.H.Q. and A.L.; supervision, A.S.A. and Z.A.A.; funding acquisition, A.S.A. All authors have read and agreed to the published version of the manuscript.

Funding: This research received no external funding.

Acknowledgments: The authors would like to thank Deanship of scientific research at King Saud University for funding and supporting this research through the initiative of DSR Graduate Students Research Support (GSR).

Conflicts of Interest: The authors declare no conflict of interest.

\section{References}

1. Mao, X.; Sun, L.; Wu, T.; Chu, T.; Deng, W.; Han, K. First-Principles Screening of All-Inorganic Lead-Free $\mathrm{ABX}_{3}$ Perovskites. J. Phys. Chem. C 2018, 122, 7670-7675. [CrossRef]

2. Im, J.H.; Lee, C.R.; Lee, J.W.; Park, S.W.; Park, N.G. 6.5\% Efficient Perovskite Quantum-Dot-Sensitized Solar Cell. Nanoscale 2011, 3, 4088-4093. [CrossRef]

3. Gao, P.; Gratzel, M.; Nazeeruddin, M.K.; Online, V.A.; Gao, P.; Nazeeruddin, M.K. Environmental Science Organohalide lead perovskites for photovoltaic applications. Energy Environ. Sci. 2014, 7, 2448-2463. [CrossRef]

4. Correa-Baena, J.P.; Abate, A.; Saliba, M.; Tress, W.; Jesper Jacobsson, T.; Grätzel, M.; Hagfeldt, A. The rapid evolution of highly efficient perovskite solar cells. Energy Environ. Sci. 2017, 10, 710-727. [CrossRef]

5. Zhao, Y.; Zhu, K. Organic-inorganic hybrid lead halide perovskites for optoelectronic and electronic applications. Chem. Soc. Rev. 2016, 45, 655-689. [CrossRef] [PubMed]

6. Sum, T.C.; Mathews, N. Advancements in perovskite solar cells: Photophysics behind the photovoltaics. Energy Environ. Sci. 2014, 7, 2518-2534. [CrossRef]

7. Eidsvåg, H.; Rasukkannu, M.; Vajeeston, P.; Velauthapillai, D. Bandgap engineering in $\mathrm{CsSn}_{x} \mathrm{~Pb}_{(1-x)} \mathrm{I}_{3}$ and their influence on light absorption. Mater. Lett. 2018, 218, 253-256. [CrossRef]

8. Maqbool, M.; Rehman, G.; Ali, L.; Shafiq, M.; Iqbal, R.; Ahmad, R.; Khan, T.; Jalali-Asadabadi, S.; Maqbool, M.; Ahmad, I. Structural, electronic and optical properties of $\mathrm{CsPbX}_{3}(\mathrm{X}=\mathrm{Cl}, \mathrm{Br}, \mathrm{I})$ for energy storage and hybrid solar cell applications. J. Alloys Compd. 2017, 705, 828-839.

9. Afsari, M.; Boochani, A.; Hantezadeh, M. Electronic, optical and elastic properties of cubic perovskite $\mathrm{CsPbI}_{3}$ : Using first principles study. Optik (Stuttg). 2016, 127, 11433-11443. [CrossRef]

10. Jishi, R.A.; Ta, O.B.; Sharif, A.A. Modeling of lead halide perovskites for photovoltaic applications. J. Phys. Chem. C 2014, 118, 28344-28349. [CrossRef]

11. Ilyas, B.M.; Elias, B.H. A theoretical study of perovskite $\mathrm{CsXCl}_{3}(\mathrm{X}=\mathrm{Pb}, \mathrm{Cd})$ within first principles calculations. Phys. B Condens. Matter 2017, 510, 60-73. [CrossRef]

12. Moore, D.T.; Kamino, B.A.; Patel, J.B.; Miranda, L.; Johnston, M.B.; Parrott, E.S.; Haghighirad, A.A.; Hörantner, M.T.; Sutton, R.J.; Snaith, H.J.; et al. Bandgap-Tunable Cesium Lead Halide Perovskites with High Thermal Stability for Efficient Solar Cells. Adv. Energy Mater. 2016, 6, 1502458.

13. Duan, J.; He, B.; Li, Y.; Tang, Q.; Zhao, Y.; Yuan, H. Lattice Modulation of Alkali Metal Cations Doped $\mathrm{Cs}_{1-\mathrm{x}} \mathrm{R}_{\mathrm{x}} \mathrm{PbBr}_{3}$ Halides for Inorganic Perovskite Solar Cells. Sol. RRL 2018, 2, 1800164.

14. Chen, X.; Han, D.; Su, Y.; Zeng, Q.; Liu, L.; Shen, D. Structural and Electronic Properties of Inorganic Mixed Halide Perovskites. Phys. Status Solidi Rapid Res. Lett. 2018, 12, 1800193. [CrossRef]

15. Shi, J.; Yun, S. First-Principles DFT Calculations for Perovskite Solar Cells. In Counter Electrodes for DyeSensitized and Perovskite Solar Cells, II; Yun, S., Hagfeldt, A., Eds.; Wiley-VCH Verlag GmbH \& Co. KGaA: Weinheim, Germany, 2018; pp. 487-509.

16. Umari, P.; Mosconi, E.; De Angelis, F. Relativistic GW calculations on $\mathrm{CH}_{3} \mathrm{NH}_{3} \mathrm{PbI}_{3}$ and $\mathrm{CH}_{3} \mathrm{NH}_{3} \mathrm{SnI}_{3}$ Perovskites for Solar Cell Applications. Sci. Rep. 2014, 4, 4467. [CrossRef] 
17. Li, B.; Zhang, Y.; Fu, L.; Yu, T.; Zhou, S.; Zhang, L.; Yin, L. Surface passivation engineering strategy to fully-inorganic cubic $\mathrm{CsPbI}_{3}$ perovskites for high-performance solar cells. Nat. Commun. 2018, 9, 1076. [CrossRef]

18. Wang, P.; Zhang, X.; Zhou, Y.; Jiang, Q.; Ye, Q.; Chu, Z.; Li, X.; Yang, X.; Yin, Z.; You, J. Solvent-controlled growth of inorganic perovskite films in dry environment for efficient and stable solar cells. Nat. Commun. 2018, 9, 2225. [CrossRef]

19. Liu, C.; Hu, M.; Zhou, X.; Wu, J.; Zhang, L.; Kong, W.; Li, X.; Zhao, X.; Dai, S.; Xu, B.; et al. Efficiency and stability enhancement of perovskite solar cells by introducing $\mathrm{CsPbI}_{3}$ quantum dots as an interface engineering layer. NPG Asia Mater. 2018, 10, 552-561. [CrossRef]

20. Wang, K.; Jin, Z.; Liang, L.; Bian, H.; Bai, D.; Wang, H.; Zhang, J.; Wang, Q.; Liu, S. All-inorganic cesium lead iodide perovskite solar cells with stabilized efficiency beyond 15\%. Nat. Commun. 2018, 9, 4544. [CrossRef]

21. Chen, M.; Ju, M.G.; Garces, H.F.; Carl, A.D.; Ono, L.K.; Hawash, Z.; Zhang, Y.; Shen, T.; Qi, Y.; Grimm, R.L.; et al. Highly stable and efficient all-inorganic lead-free perovskite solar cells with native-oxide passivation. Nat. Commun. 2019, 10, 16. [CrossRef]

22. Kohn, W.; SHAM, L.J. Self-Consistent Equations Including Exchange and Correlation Effects. Phys. Rev. 1965, 140, A1133. [CrossRef]

23. Perdew, J.P.; Burke, K.; Ernzerhof, M. Generalized gradient approximation made simple. Phys. Rev. Lett. 1996, 77, 3865-3868. [CrossRef] [PubMed]

24. Tran, F.; Blaha, P. Accurate band gaps of semiconductors and insulators with a semilocal exchange-correlation potential. Phys. Rev. Lett. 2009, 102, 226401. [CrossRef] [PubMed]

25. Bylander, D.M.; Kleinman, L. Good semiconductor band gaps with a modified local-density approximation. Phys. Rev. B 1990, 41, 7868-7871. [CrossRef]

26. Bechstedt, F.; Fuchs, F.; Kresse, G. Ab-initio theory of semiconductor band structures: New developments and progress. Phys. Status Solidi Basic Res. 2009, 246, 1877-1892. [CrossRef]

27. Camargo-Martínez, J.A.; Baquero, R. The band gap problem: The accuracy of the wien2k code confronted. Rev. Mex. Fis. 2013, 59, 453-459.

28. Heyd, J.; Peralta, J.E.; Scuseria, G.E.; Martin, R.L. Energy band gaps and lattice parameters evaluated with the Heyd-Scuseria-Ernzerhof screened hybrid functional. J. Chem. Phys. 2005, 123, 174101. [CrossRef]

29. Koller, D.; Tran, F.; Blaha, P. Improving the modified Becke-Johnson exchange potential. Phys. Rev. B Condens. Matter Mater. Phys. 2012, 85, 155109. [CrossRef]

30. Perdew, J.P.; Zunger, A. Self-interaction correction to density-functional approximations for many-electron systems. Phys. Rev. B 1981, 23, 5048-5079. [CrossRef]

31. Yuan, Y.; Xu, R.; Xu, H.T.; Hong, F.; Xu, F.; Wang, L.J. Nature of the band gap of halide perovskites $\mathrm{ABX}_{3}(\mathrm{~A}$ $\left.=\mathrm{CH}_{3} \mathrm{NH}_{3}, \mathrm{Cs} ; \mathrm{B}=\mathrm{Sn}, \mathrm{Pb} ; \mathrm{X}=\mathrm{Cl}, \mathrm{Br}, \mathrm{I}\right)$ : First-principles calculations. Chinese Phys. B 2015, 24, 116302. [CrossRef]

32. Ray, D.; Clark, C.; Pham, H.Q.; Borycz, J.; Holmes, R.J.; Aydil, E.S.; Gagliardi, L. Computational Study of Structural and Electronic Properties of Lead-Free $\mathrm{CsMI}_{3}$ Perovskites ( $\mathrm{M}=\mathrm{Ge}, \mathrm{Sn}, \mathrm{Pb}, \mathrm{Mg}, \mathrm{Ca}$, Sr, and $\left.\mathrm{Ba}\right)$. J. Phys. Chem. C 2018, 122, 7838-7848. [CrossRef]

33. He, M.; Ding, L.; Liu, S.; Shao, G.; Zhang, Z.; Liang, X.; Xiang, W. Superior fluorescence and high stability of B-Si-Zn glasses based on Mn-doped $\mathrm{CsPbBr}_{x} \mathrm{I}_{3-\mathrm{x}}$ nanocrystals. J. Alloys Compd. 2019, 780, 318-325. [CrossRef]

34. Eperon, G.E.; Stranks, S.D.; Menelaou, C.; Johnston, M.B.; Herz, L.M.; Snaith, H.J. Formamidinium lead trihalide: A broadly tunable perovskite for efficient planar heterojunction solar cells. Energy Environ. Sci. 2014, 7, 982-988. [CrossRef]

35. Castelli, I.E.; García-Lastra, J.M.; Thygesen, K.S.; Jacobsen, K.W. Bandgap calculations and trends of organometal halide perovskites. APL Mater. 2014, 2, 081514. [CrossRef]

36. Goesten, M.G.; Hoffmann, R. Mirrors of Bonding in Metal Halide Perovskites. J. Am. Chem. Soc. 2018, 140, 12996-13010. [CrossRef] [PubMed]

37. Kang, B.; Biswas, K. Exploring Polaronic, Excitonic Structures and Luminescence in $\mathrm{Cs}_{4} \mathrm{PbBr}_{6} / \mathrm{CsPbBr}_{3}$. J. Phys. Chem. Lett. 2018, 9, 830-836. [CrossRef] [PubMed]

38. Wolf, C.; Lee, T.W. Exciton and lattice dynamics in low-temperature processable $\mathrm{CsPbr}_{3}$ thin-films. Mater. Today Energy 2018, 7, 199-207. [CrossRef]

39. Zhang, M.; Zheng, Z.; Fu, Q.; Chen, Z.; He, J.; Zhang, S.; Chen, C.; Luo, W. Synthesis and single crystal growth of perovskite semiconductor $\mathrm{CsPbBr}_{3}$. J. Cryst. Growth 2018, 484, 37-42. [CrossRef] 
40. Stoumpos, C.C.; Malliakas, C.D.; Peters, J.A.; Liu, Z.; Sebastian, M.; Im, J.; Chasapis, T.C.; Wibowo, A.C.; Chung, D.Y.; Freeman, A.J.; et al. Crystal growth of the perovskite semiconductor $\mathrm{CsPbBr}_{3}$ : A new material for high-energy radiation detection. Cryst. Growth Des. 2013, 13, 2722-2727. [CrossRef]

41. Yaffe, O.; Guo, Y.; Tan, L.Z.; Egger, D.A.; Hull, T.; Stoumpos, C.C.; Zheng, F.; Heinz, T.F.; Kronik, L.; Kanatzidis, M.G.; et al. The nature of dynamic disorder in lead halide perovskite crystals. In Physical Chemistry of Interfaces and Nanomaterials XV, SPIE Nanoscience + Engineering, 28 August-1 September 2016; Bakulin, A.A., Lovrincic, R., Banerji, N., Eds.; SPIE: San Diego, CA, USA, 2016; Volume 9923, p. $99231 B$.

42. Akkerman, Q.A.; Motti, S.G.; Srimath Kandada, A.R.; Mosconi, E.; D’Innocenzo, V.; Bertoni, G.; Marras, S.; Kamino, B.A.; Miranda, L.; De Angelis, F.; et al. Solution Synthesis Approach to Colloidal Cesium Lead Halide Perovskite Nanoplatelets with Monolayer-Level Thickness Control. J. Am. Chem. Soc. 2016, 138, 1010-1016. [CrossRef] [PubMed]

43. Paul, T.; Chatterjee, B.K.; Maiti, S.; Sarkar, S.; Besra, N.; Das, B.K.; Panigrahi, K.J.; Thakur, S.; Ghorai, U.K.; Chattopadhyay, K.K. Tunable cathodoluminescence over the entire visible window from all-inorganic perovskite $\mathrm{CsPbX}_{3}$ 1D architecture. J. Mater. Chem. C 2018, 6, 3322-3333. [CrossRef]

44. Liu, Z.; Peters, J.A.; Stoumpos, C.C.; Sebastian, M.; Wessels, B.W.; Im, J.; Freeman, A.J.; Kanatzidis, M.G. Heavy metal ternary halides for room-temperature X-ray and gamma-ray detection. In Hard X-ray Gamma-ray Neutron Detect. Phys. XV, Proceedings of SPIE-The International Society for Optical Engineering, 25-29 August 2013; Fiederle, M., Burger, A., Franks, L., James, R.B., Eds.; SPIE: San Diego, CA, USA, 2013; Volume 8852, p. 88520 A.

45. Koller, D.; Tran, F.; Blaha, P. Merits and limits of the modified Becke-Johnson exchange potential. Phys. Rev. B 2011, 83, 195134. [CrossRef]

46. Rubel, O.; Bokhanchuk, A.; Ahmed, S.J.; Assmann, E. Unfolding the band structure of disordered solids: From bound states to high-mobility Kane fermions. Phys. Rev. B Condens. Matter Mater. Phys. 2014, 90, 115202. [CrossRef]

47. Maspero, R.; Sweeney, S.J.; Florescu, M. Unfolding the band structure of GaAsBi. J. Phys. Condens. Matter 2017, 29, 075001. [CrossRef]

48. Medeiros, P.V.C.; Stafström, S.; Björk, J. Effects of extrinsic and intrinsic perturbations on the electronic structure of graphene: Retaining an effective primitive cell band structure by band unfolding. Phys. Rev. B Condens. Matter Mater. Phys. 2014, 89, 041407. [CrossRef]

49. Hohenberg, P.; Kohn, W. Inhomogeneous Electron Gas. Phys. Rev. 1964, 134, B864. [CrossRef]

50. Nordström, L.; Madsen, G.K.H.; Blaha, P.; Schwarz, K.; Sjöstedt, E. Efficient linearization of the augmented plane-wave method. Phys. Rev. B Condens. Matter Mater. Phys. 2001, 64, 195134.

51. Blaha, P.; Schwarz, K.; Luitz, G.K.H.M.D.K.J.; Tran, R.L.F.; Marks, L.D. An Augmented Plane Wave Plus Local Orbitals Program for Calculating Crystal Properties, 3rd-9501031st-ed.; Schwarz, K., Ed.; Vienna University of Technology: Vienna, Austria, 2019; Volume 2, ISBN 3-9501031-1-2.

52. Momma, K.; Izumi, F. VESTA 3 for three-dimensional visualization of crystal, volumetric and morphology data. J. Appl. Crystallogr. 2011, 44, 1272-1276. [CrossRef]

53. Ghaithan, H.M.; Alahmed, Z.A.; Qaid, S.M.H.; Aldwayyan, A.S. First principle-based calculations of the optoelectronic features of $2 \times 2 \times 2 \mathrm{CsPb}\left(\mathrm{I}_{1-\mathrm{x}} \mathrm{Br}_{\mathrm{x}}\right)_{3}$ perovskite. Superlattices Microstruct. 2020, 140, 106474. [CrossRef]

54. Trots, D.M.; Myagkota, S.V. High-temperature structural evolution of caesium and rubidium triiodoplumbates. J. Phys. Chem. Solids 2008, 69, 2520-2526. [CrossRef]

55. Eperon, G.E.; Paternò, G.M.; Sutton, R.J.; Zampetti, A.; Haghighirad, A.A.; Cacialli, F.; Snaith, H.J. Inorganic caesium lead iodide perovskite solar cells. J. Mater. Chem. A 2015, 3, 19688-19695. [CrossRef]

56. Ghaithan, H.M.; Alahmed, Z.A.; Qaid, S.M.H.; Hezam, M.; Aldwayyan, A.S. Density Functional Study of Cubic, Tetragonal, and Orthorhombic $\mathrm{CsPbBr}_{3}$ Perovskite. ACS Omega 2020, 5, 7468-7480. [CrossRef] [PubMed]

57. Murtaza, G.; Ahmad, I. First principle study of the structural and optoelectronic properties of cubic perovskites $\mathrm{CsPbM}_{3}(\mathrm{M}=\mathrm{Cl}, \mathrm{Br}$ I). Phys. B Condens. Matter 2011, 406, 3222-3229. [CrossRef]

58. Sandor, E.; Wooster, W.A. Crystal Structure and Photoconductivity of Cæsium Plumbohalides. Nature 1958, $182,1436$.

59. Dixit, H.; Saniz, R.; Cottenier, S.; Lamoen, D.; Partoens, B. Electronic structure of transparent oxides with the Tran-Blaha modified Becke-Johnson potential. J. Phys. Condens. Matter 2012, 24, 205503. [CrossRef] 
60. Fan, S.W.; Ding, L.J.; Yao, K.L. Electronic structure and ferromagnetism of boron doped bulk and surface CdSe: By generalized gradient approximation and generalized gradient approximation plus modified Becke and Johnson calculations. J. Appl. Phys. 2013, 114, 113905. [CrossRef]

61. Traoré, B.; Bouder, G.; Lafargue-Dit-Hauret, W.; Rocquefelte, X.; Katan, C.; Tran, F.; Kepenekian, M. Efficient and accurate calculation of band gaps of halide perovskites with the Tran-Blaha modified Becke-Johnson potential. Phys. Rev. B 2019, 99, 035139. [CrossRef]

62. Popescu, V.; Zunger, A. Effective band structure of random alloys. Phys. Rev. Lett. 2010, 104, 236403. [CrossRef]

63. Popescu, V.; Zunger, A. Extracting E versus $\vec{k}$ Effective band structure from supercell calculations on alloys and impurities. Phys. Rev. B Condens. Matter Mater. Phys. 2012, 85, 085201. [CrossRef]

64. Chen, M.X.; Weinert, M. Revealing the substrate origin of the linear dispersion of Silicene/Ag(111). Nano Lett. 2014, 14, 5189-5193. [CrossRef] [PubMed]

65. Lang, L.; Yang, J.H.; Liu, H.R.; Xiang, H.J.; Gong, X.G. First-principles study on the electronic and optical properties of cubic $\mathrm{ABX}_{3}$ halide perovskites. Phys. Lett. A 2014, 378, 290-293. [CrossRef]

66. Heidrich, K.; Schäfer, W.; Schreiber, M.; Söchtig, J.; Trendel, G.; Treusch, J.; Grandke, T.; Stolz, H.J. Electronic structure, photoemission spectra, and vacuum-ultraviolet optical spectra of $\mathrm{CsPbl}_{3}$ and $\mathrm{CsPbr}_{3}$. Phys. Rev. B 1981, 24, 5642-5649. [CrossRef]

67. Wang, K.; Yang, Q.; Duan, J.; Zhang, C.; Zhao, F.; Yu, H.; Hu, B. Spin-Polarized Electronic Transport through Ferromagnet/Organic-Inorganic Hybrid Perovskite Spinterfaces at Room Temperature. Adv. Mater. Interfaces 2019, 1, 1900718. [CrossRef]

68. Qaid, S.M.H.; Al-Asbahi, B.A.; Ghaithan, H.M.; AlSalhi, M.S.; Al dwayyan, A.S. Optical and structural properties of $\mathrm{CsPBr}_{3}$ perovskite quantum dots/PFO polymer composite thin films. J. Colloid Interface Sci. 2020, 563, 426-434. [CrossRef]

69. Ghebouli, M.A.; Ghebouli, B.; Fatmi, M. First-principles calculations on structural, elastic, electronic, optical and thermal properties of $\mathrm{CsPbl}_{3}$ perovskite. Phys. B Condens. Matter 2011, 406, 1837-1843. [CrossRef]

70. Amin, B.; Ahmad, I.; Maqbool, M.; Goumri-Said, S.; Ahmad, R. Ab initio study of the bandgap engineering of $\mathrm{Al}_{1-\mathrm{x}} \mathrm{Ga}_{\mathrm{x}} \mathrm{N}$ for optoelectronic applications. J. Appl. Phys. 2011, 109, 023109. [CrossRef]

71. Xu, B.; Li, X.; Sun, J.; Yi, L. Electronic structure, ferroelectricity and optical properties of $\mathrm{CaBi}_{2} \mathrm{Ta}_{2} \mathrm{O}_{9}$. Eur. Phys. J. B 2008, 66, 483-487. [CrossRef]

(C) 2020 by the authors. Licensee MDPI, Basel, Switzerland. This article is an open access article distributed under the terms and conditions of the Creative Commons Attribution (CC BY) license (http://creativecommons.org/licenses/by/4.0/). 